Journal of Organometallic Chemistry, 277 (1984) 395-401

Elsevier Sequoia S.A., Lausanne - Printed in The Netherlands

\title{
CRYSTAL AND MOLECULAR STRUCTURE OF TRICLINIC $\left[\mathrm{C}_{5} \mathrm{H}_{5}(\mathrm{CO})_{2} \mathrm{Mo}_{2}\left(\mu, \eta^{2}-\mathrm{C}=\mathrm{NC}_{6} \mathrm{H}_{5}\right)\right.$ AND COMPARISON WITH ITS MONOCLINIC FORM
}

\section{BERNAL,}

Department of Chemistry, University of Houston, Houston, Texas 77004 (U.S.A.)

H. BRUNNER and J. WACHTER

Institut für Anorganische Chemie der Universität Regensburg, Universitätsstr. 31, D-8400 Regensburg (F.R.G.)

(Received June 25th, 1984)

\section{Summary}

The crystal and molecular structure of $\left[\mathrm{C}_{5} \mathrm{H}_{5}(\mathrm{CO})_{2} \mathrm{Mo}\right]_{2}\left(\mu, \eta^{2}-\mathrm{C} \equiv \mathrm{NC}_{6} \mathrm{H}_{5}\right)$ were determined for a new polymorphic form in which the substance crystallizes in the triclinic system, as opposed to the monoclinic form previously describcd. The space group is $P \overline{1}$ and the lattice constants are $a 9.795(2), b$ 10.219(3), $c$ 11.505(3) $\AA, \alpha$ 81.53(2), $\beta$ 70.83(2) and $\gamma 66.91(2)^{\circ}, V 997.70 \AA^{3}$ and $D(Z=2)=1.788 \mathrm{~g} \mathrm{~cm}^{-3}$. The Niggli matrix rules out the possibility that the triclinic cell is a sub-cell of the monoclinic one previously described. Detailed comparison of bond lengths, angles, torsional angles and superposition of the two molecules through the BMFIT program show that the two determinations yield very close but not identical results, and that the largest deviations are associated with those groups ( $\mathrm{Cp}$ and phenyl), which are able to respond readily to differences in packing forces. It is clear, however, that the general conformation of the molecules is not dictated by such forces, which merely modify the intramolecular forces controlling conformation and configuration.

\section{Introduction}

The reaction of $\mathrm{Cp}(\mathrm{CO})_{2} \mathrm{Mo} \equiv \mathrm{Mo}(\mathrm{CO})_{2} \mathrm{Cp}\left(\mathrm{Cp}=\eta-\mathrm{C}_{5} \mathrm{H}_{5}\right)$ with an excess of diphenylcarbodiimide, $\mathrm{C}_{6} \mathrm{H}_{5} \mathrm{~N}=\mathrm{C}=\mathrm{NC}_{6} \mathrm{H}_{5}$, leads to the new asymmetrically bridged complex $\mathrm{Cp}_{2}(\mathrm{CO})_{2} \mathrm{Mo}_{2} \mu\left(\eta^{1}: \eta^{2}-\mathrm{C}_{6} \mathrm{H}_{5} \mathrm{~N}=\mathrm{C}=\mathrm{NC}_{6} \mathrm{H}_{5}\right)$, I, and to $\mathrm{Cp}_{2}(\mathrm{CO})_{4^{-}}$ $\mathrm{Mo}_{2} \mu\left(\eta^{1}: \eta^{2}-\mathrm{C} \equiv \mathrm{NC}_{6} \mathrm{H}_{5}\right)$, II [1] (Scheme 1).

During our attempts to prepare single crystals of complex $\mathrm{I}$, in which the $\mathrm{Mo} \equiv \mathrm{Mo}$ bond is preserved, thus giving rise to a compound having reactivity similar to that of $\left[\mathrm{Cp}(\mathrm{CO})_{2} \mathrm{Mo}\right]_{2}$, we separated a substance crystallizing in the triclinic system with 
SCHEME 1

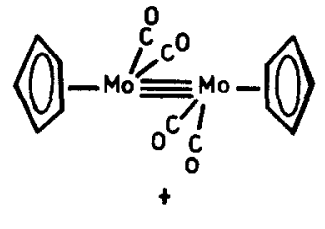

$\mathrm{PhN}=\mathrm{C}=\mathrm{NPh}$

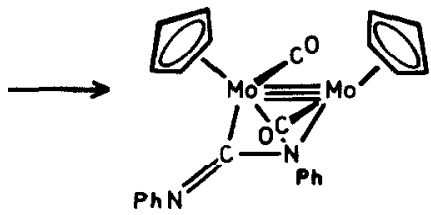

I

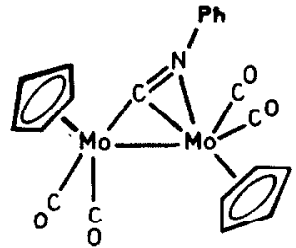

II

space group $P \overline{1}$. Analysis by $\mathrm{X}$-ray diffraction showed this compound to be $\mathrm{Cp}_{2}(\mathrm{CO})_{4} \mathrm{Mo}_{2}\left(\eta^{1}: \eta^{2}-\mathrm{C} \equiv \mathrm{NC}_{6} \mathrm{H}_{5}\right)$. This result was somewhat surprising, since the same complex was reported by Adams et al. [2] to be monoclinic $\left(P 2_{1} / n\right)$, although both structure determinations were carried out at about the same temperature. Consequently, this study constitutes a separate and independent determination of the crystal and molecular structure of compound II. The phenomenon of polymorphism is somewhat rare for organometallic compounds [3], but it is of interest, for it allows us to see the effect of packing on molecular conformation and configuration. Thus, therefore in this paper we compare our and Adams' results, for they are of

TABI.F. 1

SUMMARY OF DATA COLLECTION AND PROCESSING PARAMETERS

\begin{tabular}{|c|c|}
\hline Space group & $P \overrightarrow{1}$ \\
\hline \multirow[t]{6}{*}{ Cell constants } & $a 9.795(2) \AA$ \\
\hline & b $10.219(3)$ \\
\hline & $c 11.505(3)$ \\
\hline & $\alpha 81.53(2)^{\circ}$ \\
\hline & $\beta 70.38(2)$ \\
\hline & $\gamma 66.91(2)$ \\
\hline Cell volume & $V 997.70 \AA^{3}$ \\
\hline Crystal aligned nearly along & {$[0,1,2]$} \\
\hline Molecular formula & $\mathrm{C}_{21} \mathrm{H}_{15} \mathrm{NO}_{4} \mathrm{Mo}_{2}$ \\
\hline Molecular weight & 537.238 \\
\hline Density (calc.; $Z=2$ ) & $1.788 \mathrm{~g} \mathrm{~cm}^{-3}$ \\
\hline Radiation & Mo- $K_{\alpha}$ \\
\hline Absorption coefficient & $\mu 11.51 \mathrm{~cm}^{-1}$ \\
\hline Data collection range & $4.0^{\circ} \leqslant 2 \theta \leqslant 60.0^{\circ}$ \\
\hline Scan width & $\Delta \theta=(1.0+0.35 \tan \theta)$ \\
\hline Maximum scan time & 180 seconds \\
\hline Scan speed range & 0.53 to $6.70 \mathrm{deg} \min ^{-1}$ \\
\hline Total data collected & 6419 data $^{a}$ \\
\hline Data with $I>3 \sigma(I)$ & 3688 \\
\hline Total variables & 144 (Cp and $P h$ as rigid bodles). \\
\hline$R=\Sigma|| F_{0}|-| F_{\mathrm{c}} \| / \Sigma\left|F_{0}\right|$ & 0.0526 \\
\hline$R_{w}=\left[\Sigma w^{2}\left(\left|F_{0}\right|-\left|F_{c}\right|\right)^{2} / \Sigma w^{2}\left|F_{0}\right|^{2}\right]^{1 / 2}$ & 0.0471 \\
\hline Weights & $\mu=\left[\sigma\left(F_{0}\right)\right]^{-2}$ \\
\hline Goodness of fit & 3.81 \\
\hline
\end{tabular}

${ }^{a}$ Of these, 2731 were eliminated because they were intensity standards, were redundant, or did not meet the criterion of having I $>3 \sigma(1)$. 
similar high quality. The discrepancies between the two determinations are given in the form of a BMFIT plot and BMFIT data.

\section{Experimental}

The data were collected at room temperature, using standard techniques as described in detail elsewhere [4]. Complex II crystallizes in the triclinic system as

TABLE 2

ATOMIC COORDINATES FOR $\left[\eta-\mathrm{C}_{5} \mathrm{H}_{5}(\mathrm{CO})_{2} \mathrm{Mo}\right]_{2}\left(\mu, \eta^{2}-\mathrm{CNC}_{6} \mathrm{H}_{5}\right)$

\begin{tabular}{|c|c|c|c|}
\hline Atom & $x / a$ & $y / b$ & $z / c$ \\
\hline$\overline{M o(1)}$ & $0.23060(7)$ & $0.10170(6)$ & $0.28296(5)$ \\
\hline $\operatorname{Mo}(2)$ & $0.43225(6)$ & $0.29352(6)$ & $0.26808(5)$ \\
\hline$O(1)$ & $0.1014(6)$ & $0.2216(6)$ & $0.5462(5)$ \\
\hline$O(2)$ & $0.6367(8)$ & $0.0039(7)$ & $0.3594(7)$ \\
\hline$O(3)$ & $-0.1288(6)$ & $0.2491(7)$ & $0.3436(6)$ \\
\hline$O(4)$ & $0.7357(8)$ & $0.2272(10)$ & $0.0484(7)$ \\
\hline $\mathrm{N}(1)$ & $0.2565(6)$ & $0.2283(6)$ & $0.1122(5)$ \\
\hline$C(5)$ & $0.3370(7)$ & $0.2528(7)$ & $0.1625(6)$ \\
\hline $\mathrm{C}(17)$ & $0.1563(8)$ & $0.1790(8)$ & $0.4474(6)$ \\
\hline$C(18)$ & $0.5540(10)$ & $0.1124(10)$ & $0.3271(8)$ \\
\hline$C(19)$ & $0.0040(10)$ & $0.1991(8)$ & $0.3193(6)$ \\
\hline$C(20)$ & $0.6240(10)$ & $0.2493(10)$ & $0.1295(9)$ \\
\hline $\mathrm{C}(0)$ & $0.2234(5)$ & $-0.1052(6)$ & $0.2282(5)$ \\
\hline$C(1)$ & $0.2214(5)$ & $-0.1148(8)$ & $0.3531(5)$ \\
\hline$C(2)$ & $0.3672(5)$ & $-0.1180(6)$ & $0.3544(5)$ \\
\hline$C(3)$ & $0.4592(5)$ & $-0.1103(6)$ & $0.2302(5)$ \\
\hline $\mathrm{C}(4)$ & $0.3704(5)$ & $-0.1024(6)$ & $0.1523(5)$ \\
\hline$C(6)$ & $0.1995(5)$ & $0.2828(5)$ & $0.0120(3)$ \\
\hline$c(7)$ & $0.1311(5)$ & $0.2109(5)$ & $-0.0307(3)$ \\
\hline $\mathrm{C}(8)$ & $0.0819(5)$ & $0.2618(5)$ & $-0.1348(3)$ \\
\hline$C(9)$ & $0.1011(5)$ & $0.3847(5)$ & $-0.1962(3)$ \\
\hline$C(10)$ & $0.1694(5)$ & $0.4567(5)$ & $-0.1534(3)$ \\
\hline$C(11)$ & $0.2187(5)$ & $0.4057(5)$ & $-0.0493(3)$ \\
\hline $\mathrm{C}(12)$ & $0.3404(7)$ & $0.4053(6)$ & $0.4586(5)$ \\
\hline $\mathrm{C}(13)$ & $0.4732(7)$ & $0.4359(6)$ & $0.3840(5)$ \\
\hline $\mathrm{C}(14)$ & $0.4365(7)$ & $0.5174(6)$ & $0.2799(5)$ \\
\hline$C(15)$ & $0.2811(7)$ & $0.5372(6)$ & $0.2903(5)$ \\
\hline$C(16)$ & $0.2217(7)$ & $0.4679(6)$ & $0.4008(5)$ \\
\hline $\mathrm{H}(0)$ & $0.1365(5)$ & $-0.1011(6)$ & $0.1989(5)$ \\
\hline $\mathrm{H}(1)$ & $0.1330(5)$ & $-0.1186(6)$ & $0.4272(5)$ \\
\hline $\mathrm{H}(2)$ & $0.3993(5)$ & $-0.1244(6)$ & $0.4295(5)$ \\
\hline$H(3)$ & $0.5676(5)$ & $-0.1104(6)$ & $0.2026(5)$ \\
\hline$H(4)$ & $0.4052(5)$ & $-0.0960(6)$ & $0.0601(5)$ \\
\hline$H(7)$ & $0.1174(5)$ & $0.1227(5)$ & $0.0133(3)$ \\
\hline $\mathbf{H}(8)$ & $0.0329(5)$ & $0.2102(5)$ & $-0.1655(3)$ \\
\hline $\mathrm{H}(9)$ & $0.0658(5)$ & $0.4212(5)$ & $-0.2708(3)$ \\
\hline$H(10)$ & $0.1832(5)$ & $0.5448(5)$ & $-0.1974(3)$ \\
\hline $\mathrm{H}(11)$ & $0.2677(5)$ & $0.4573(5)$ & $-0.0187(3)$ \\
\hline $\mathrm{H}(12)$ & $0.3320(7)$ & $0.3495(6)$ & $0.5381(5)$ \\
\hline $\mathrm{H}(13)$ & $0.5747(7)$ & $0.4054(6)$ & $0.4016(5)$ \\
\hline $\mathrm{H}(14)$ & $0.5077(7)$ & $0.5544(6)$ & $0.2114(5)$ \\
\hline $\mathrm{H}(15)$ & $0.2236(7)$ & $0.5906(6)$ & $0.2303(5)$ \\
\hline$H(16)$ & $0.1150(7)$ & $0.4639(6)$ & $0.4322(5)$ \\
\hline
\end{tabular}


shown by the Niggli matrix:

$\left[\begin{array}{lll}S_{11} & S_{22} & S_{33} \\ S_{23} & S_{13} & S_{12}\end{array}\right]=\left[\begin{array}{rrr}95.7949 & 104.4358 & 132.3707 \\ 17.3017 & 37.8361 & 39.2636\end{array}\right]$

which allows no transformation of the triclinic cell used here to any other crystal system.

The parameters used in programming data collection and those parameters derived from data collection and processing are summarized in Table 1 . The structure was solved by the heavy atom method and the refined values of the atomic coordinates are given in Table 2. Tables of thermal parameters and structure factors may be obtained from the authors on request.

\section{Discussion}

The molecular geometry of II is depicted in Fig. 1, showing the same trans arrangement of $\mathrm{Cp}$ rings as was present in the structure determined by Adams [2]. Figure 2 is a BMFIT [6] double sterco plot comparing II as determined here with the Adams coordinates. As can be seen, the fit is not exact, and in certain locations some of the deviations are fairly large. Table 3 gives a list of these deviations, the largest of which are associated with the most remote atoms of the phenyl ring. This is not too surprising since this ring has a large area over which packing forces can exert bending and torsional changes. The next largest deviations are associated with the $\mathrm{Cp}$ ring on the left of Fig. 2 (which was drawn in exactly the same orientation), but these deviations are smaller. What is, in fact, surprising is that there are relatively modest deviations overall and particularly that the torsional orientations of the two $\mathrm{Cp}$ rings remain virtually unchanged, since it is known from NMR data that in solution these rings are free to rotate. Thus, it seems that while packing forces clearly
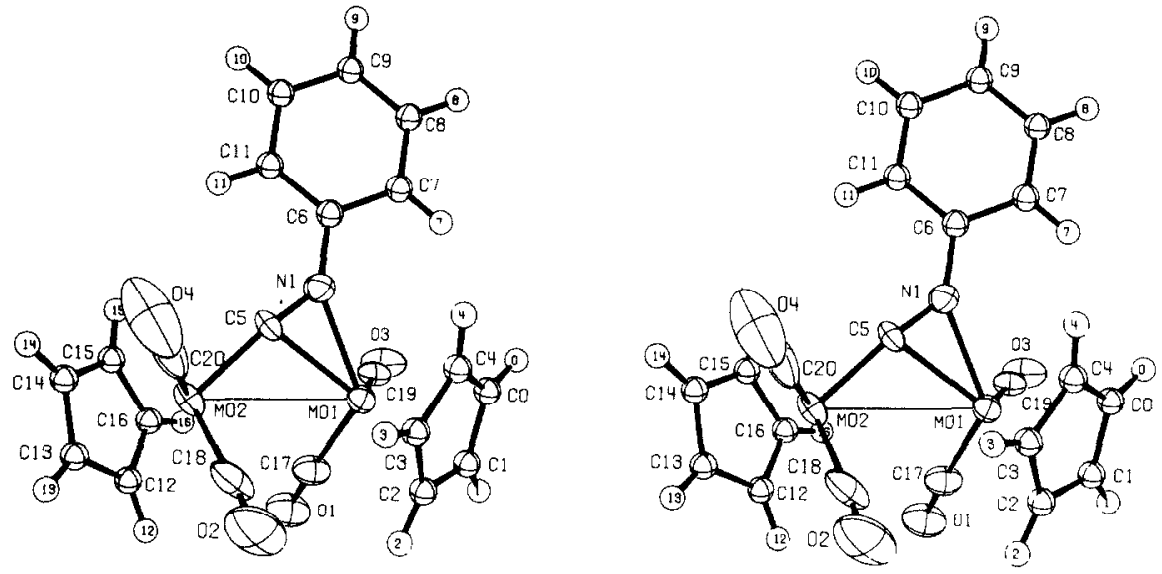

Fig. 1. Stereo representation of molecule II showing the numbering system used in the crystallographic study. The thermal ellipsoids are $50 \%$ equiprobability envelopes for the heavy atoms, hydrogens were drawn of convenient size for representational purposes and to minimize undesirable obscuration of the heavy atom framework. The hydrogen atoms are labelled according to the number of the carbon atoms to which they are attached. 
TABLE 3

SELECTED BOND DISTANCES (Ä) AND BOND ANGLES (Deg) FOR $\left[\eta-\mathrm{C}_{5} \mathrm{H}_{5}(\mathrm{CO})_{2} \mathrm{Mo}\right]_{2}\left(\mu, \eta^{2}-\right.$ $\mathrm{CNC}_{6} \mathrm{H}_{5}$ )

\begin{tabular}{|c|c|c|c|}
\hline \multicolumn{4}{|l|}{ Band lengths } \\
\hline $\operatorname{Mo}(1)-\operatorname{Mo}(2)$ & $3.238(1)$ & $\mathrm{Mo}(2)-\mathrm{C}(5)$ & $1.932(8)$ \\
\hline $\operatorname{Mo}(1)-N(1)$ & $2.185(7)$ & $\mathrm{Mo}(2)-\mathrm{C}(18)$ & $1.937(12)$ \\
\hline $\operatorname{Mo}(1)-C(5)$ & $2.248(8)$ & $\mathrm{Mo}(2)-\mathrm{C}(20)$ & $1.952(11)$ \\
\hline$M o(1)-C(17)$ & $1.948(9)$ & $\operatorname{Mo}(2)-C(12)$ & $2.351(7)$ \\
\hline $\mathrm{Mo}(1)-\mathrm{C}(19)$ & $1.964(11)$ & $\operatorname{Mo}(2)-C(13)$ & $2.333(8)$ \\
\hline $\operatorname{Mo}(1)-C(0)$ & $2.326(7)$ & $\mathrm{Mo}(2)-\mathrm{C}(14)$ & $2.329(7)$ \\
\hline $\operatorname{Mo}(1)-C(1)$ & $2.266(7)$ & $\operatorname{Mo}(2)-C(15)$ & $2.345(7)$ \\
\hline $\operatorname{Mo}(1)-C(2)$ & $2.311(7)$ & $\mathrm{Mo}(2)-\mathrm{C}(16)$ & $2.359(8)$ \\
\hline $\mathrm{Mo}(1)-\mathrm{C}(3)$ & $2.397(7)$ & & \\
\hline \multirow[t]{3}{*}{$\operatorname{Mo}(1)-C(4)$} & $2.406(7)$ & & \\
\hline & & $\mathrm{O}(1)-\mathrm{C}(17)$ & $1.15(1)$ \\
\hline & & $\mathrm{O}(2)-\mathrm{C}(18)$ & $1.82(2)$ \\
\hline$N(1)-C(5)$ & $1.234(9)$ & $O(3)-C(19)$ & $1.14(2)$ \\
\hline$N(1)-C(6)$ & $1.395(8)$ & $\mathrm{O}(4)-\mathrm{C}(20)$ & $1.14(1)$ \\
\hline \multicolumn{4}{|l|}{ Bond angles } \\
\hline $\operatorname{Mo}(2)-\operatorname{Mo}(1)-\mathrm{N}(1)$ & $68.0(2)$ & $\operatorname{Mo}(1)-\operatorname{Mo}(2)-C(5)$ & $42.9(2)$ \\
\hline $\mathrm{M} \propto(2)-\mathrm{Mo}(1)-\mathrm{C}(5)$ & $35.8(2)$ & $\mathrm{Mo}(1)-\mathrm{Mo}(2)-\mathrm{C}(18)$ & $78.2(3)$ \\
\hline$N(1)-M o(1)-C(5)$ & $32.3(2)$ & $\mathrm{Mo}(1)-\mathrm{Mo}(2)-\mathrm{C}(20)$ & $114.0(3)$ \\
\hline $\mathrm{Mo}(2)-\mathrm{Mo}(1)-\mathrm{C}(17)$ & $74.7(3)$ & $\mathrm{C}(5)-\mathrm{M} O(2)-\mathrm{C}(18)$ & $107.0(4)$ \\
\hline$M o(2)-M o(1)-C(19)$ & $117.5(3)$ & $C(5)-M o(2)-C(20)$ & $87.8(4)$ \\
\hline $\mathrm{N}(1)-\mathrm{Mo}(1)-\mathrm{C}(17)$ & $124.3(3)$ & $C(18)-M o(2)-C(20)$ & $80.9(5)$ \\
\hline $\mathrm{C}(5)-\mathrm{Mo}(1)-\mathrm{C}(17)$ & $103.3(4)$ & & \\
\hline $\mathrm{N}(1)-\mathrm{Mo}(1)-\mathrm{C}(19)$ & $87.7(3)$ & $M o(2)-C(5)-N(1)$ & $169.7(7)$ \\
\hline $\mathrm{C}(5)-\mathrm{Mo}(1)-\mathrm{C}(19)$ & $106.1(3)$ & $\mathrm{Mo}(2)-\mathrm{C}(18)-\mathrm{O}(2)$ & $175.8(1.2)$ \\
\hline $\mathrm{C}(17)-\mathrm{Mo}(1)-\mathrm{C}(19)$ & $74.3(4)$ & $\mathrm{Mo}(2)-\mathrm{C}(20)-\mathrm{O}(4)$ & $178.1(1.2)$ \\
\hline $\operatorname{Mo}(1) \mathrm{C}(5)-\operatorname{Mo}(2)$ & $101.3(3)$ & & \\
\hline$M o(1)-N(1)-C(5)$ & $76.7(5)$ & & \\
\hline$M o(1)-N(1)-C(6)$ & $145.2(5)$ & & \\
\hline $\mathrm{Mo}(1)-\mathrm{C}(17)-\mathrm{O}(1)$ & $174.0(9)$ & & \\
\hline $\mathrm{Mo}(1)-\mathrm{C}(19)-\mathrm{O}(3)$ & $176.3(9)$ & & \\
\hline$C(5)-N(1)-C(6)$ & $136.9(7)$ & & \\
\hline
\end{tabular}
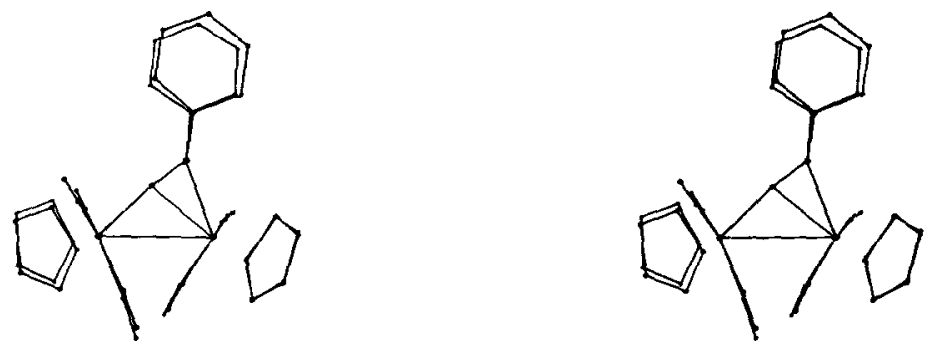

Fig. 2. BMFIT comparison of the stereochemistry of the molecules present in our crystalline polymorph(triclinic) vs. that of the ones present in the polymorph(monoclinic) studied by Adams et al. In order to generate this Figure, the least-squares fitting routine of BMFIT was asked to match as perfectly as possible $\mathrm{Mo}(1), \mathrm{Mo}(2), \mathrm{C}(5)$, and $\mathrm{N}$. No effort was made to fit the other ones. Nonetheless, it should be noted that the conformation of the $\mathrm{C}_{\mathrm{p}}$ ring on the lower right is almost perfect while that of the ring on the other side and the phenyl ring have slightly different orientations. For details of the numerical differences (in $\AA$ ) of the two sets of atoms, see Tables 4 and 5 . 
TABLE 4

DIFFERENCES $(\breve{A})$ IN THE TWO FORMS OF $\left[\mathrm{C}_{5} \mathrm{H}_{5}(\mathrm{CO})_{2} \mathrm{Mo}\right]_{2}\left(\mu_{v} \eta^{2}-\mathrm{CNC}_{6} \mathrm{H}_{5}\right)$ EXPRESSED AS DISTANCES BETWEEN ATOMS

\begin{tabular}{|c|c|c|c|c|c|}
\hline Atom 1 & Atom $2^{\circ}$ & Distance & Atom 1 & Atom 2 & Distance \\
\hline $\operatorname{Mo}(1)$ & $\operatorname{Mo}(1)$ & 0.020 & $C(1)$ & $\mathrm{C}(\mathrm{P} 12)$ & 0.080 \\
\hline $\mathrm{Mo}(2)$ & $\operatorname{Mo}(2)$ & 0.017 & $C(2)$ & $C(P 11)$ & 0.076 \\
\hline$N(1)$ & $N$ & 0.021 & $C(3)$ & $C($ P15) & 0.078 \\
\hline$C(5)$ & $C(31)$ & 0.022 & $C(4)$ & $C(P 14)$ & 0.079 \\
\hline$C(6)$ & $C(31)$ & 0.229 & $\mathrm{C}(7)$ & $C(36)$ & 0.314 \\
\hline$O(1)$ & $O(1)$ & 0.239 & $C(8)$ & $C(35)$ & 0.568 \\
\hline$O(2)$ & $O(3)$ & 0.414 & $C(9)$ & $C(34)$ & 0.777 \\
\hline$O(3)$ & $O(2)$ & 0.196 & $C(10)$ & $C(33)$ & 0.726 \\
\hline$O(4)$ & $O(4)$ & 0.431 & $C(11)$ & $C(32)$ & 0.445 \\
\hline $\mathrm{C}(17)$ & $\mathrm{C}(1)$ & 0.135 & $C(13)$ & $\mathrm{C}(\mathrm{P} 24)$ & 0.235 \\
\hline$C(18)$ & $C(3)$ & 0.246 & $C(14)$ & $\mathrm{C}(\mathrm{P} 23)$ & 0214 \\
\hline$C(19)$ & $C(2)$ & 0.116 & $C(15)$ & $\mathrm{C}(\mathbf{P} 22)$ & 0200 \\
\hline $\mathrm{C}(20)$ & $C(4)$ & 0.245 & $\mathrm{C}(16)$ & $\mathrm{C}(\mathbf{P} 21)$ & 0.212 \\
\hline $\mathrm{C}(0)$ & $\mathrm{C}(\mathrm{P} 13)$ & 0.082 & & & \\
\hline
\end{tabular}

"Atom labelling corresponds to ref. 2.

affect the details of the conformational orientations of the two crystalline forms of II. they do not completely determine the molecular conformation in this case. It is also interesting to note that despite the ability of molecule II to display crystal polymorphism it does so while retaining the $\mathrm{Cp}$ rings in the trans conformation.

TABLE 5

DIFFERENCES (A) IN BOND LENGTHS AND BOND ANGLES $(\%$ BETWEEN THE TWO FORMS OF $\left[\mathrm{C}_{5} \mathrm{H}_{5}(\mathrm{CO})_{2} \mathrm{Mo}_{2}\left(\mu, \eta^{2}-\mathrm{CNC}_{6} \mathrm{H}_{5}\right)\right.$

\begin{tabular}{|c|c|c|}
\hline Bund lengths $(\Delta d)$ & & \\
\hline Molecule (this work) & Molecule (ref. 2) & $\Delta d$ \\
\hline $\operatorname{Mo}(1)-\operatorname{Mo}(2)$ & $\operatorname{Mo}(1)-\operatorname{Mo}(2)$ & 0.026 \\
\hline$M o(1)-N(1)$ & $\operatorname{Mo}(1)-N$ & 0.020 \\
\hline$M o(1)-C(5)$ & $\operatorname{Mo}(1)-C(5)$ & 0.001 \\
\hline$M o(2)-N(1)$ & $\operatorname{Mo}(2)-N$ & 0.012 \\
\hline$M o(2)-C(5)$ & $\operatorname{Mo}(2)-C(5)$ & 0.009 \\
\hline$N(1)-C(5)$ & $\mathrm{N}-\mathrm{C}(5)$ & 0.008 \\
\hline Bond angles $(\Delta \omega)$ & & \\
\hline Molecule (this work) & Molecule (ref. 2) & $\Delta \omega$ \\
\hline $\operatorname{Mo}(2)-\operatorname{Mo}(1)-N(1)$ & $\operatorname{Mo}(2)-M o(1)-N$ & 0.7 \\
\hline$M o(2)-M o(1)-C(5)$ & $\mathrm{Mo}(2) \sim \mathrm{Mo}(1)-\mathrm{C}(5)$ & 0.7 \\
\hline$N(1)-M o(1)-C(5)$ & $\mathrm{N}-\mathrm{Mo}(1)-\mathrm{C}(5)$ & 0.1 \\
\hline$M o(1)-M o(2)-N(1)$ & $M o(1)-M o(2)-N$ & 0.5 \\
\hline $\mathrm{Mo}(1)-\mathrm{Mo}(2)-\mathrm{C}(5)$ & $\operatorname{Mo}(1)-\operatorname{Mo}(2)-C(5)$ & 0.6 \\
\hline $\mathrm{N}(1)-\mathrm{M} \circ(2)-\mathrm{C}(5)$ & $\mathrm{N}-\mathrm{Mo}(2)-\mathrm{C}(5)$ & 0.7 \\
\hline $\operatorname{Mo}(1)-N(1)-\operatorname{Mo}(2)$ & $\mathrm{Mo}(1)-\mathrm{N}-\mathrm{Mo}(2)$ & 1.2 \\
\hline$M \circ(1)-N(1)-C(5)$ & $\mathrm{Mo}(1)-\mathrm{N} \sim \mathrm{C}(5)$ & 1.0 \\
\hline$M \cap(2)-N(1)-C(5)$ & $M o(2)-N-C(5)$ & 1.1 \\
\hline $\operatorname{Mo}(1)-C(5)-\operatorname{Mo}(2)$ & $M o(1)-C(5)-M \propto(2)$ & 1.3 \\
\hline$M o(1)-C(5)-N(1)$ & $M o(1)-C(5)-N$ & 0.9 \\
\hline$M o(2)-C(5)-N(1)$ & $\mathrm{Mo}(2)-\mathrm{C}(5)-\mathrm{N}$ & 1.9 \\
\hline
\end{tabular}




\section{Acknowledgements}

Ivan Bernal thanks the Robert A. Welch Foundation and the US National Science Foundation for support.

\section{References}

1 H. Brunner, B. Hoffmann and J. Wachter, J. Organomet. Chem., 252 (1983) C35.

2 R.D. Adams, D.A. Katahira and L.-W. Yang, Organometallics, 1 (1982) 231.

3 See for example $\left[\mathrm{C}_{5} \mathrm{H}_{5} \mathrm{FeS}\right]_{4}$, which has been studied as orthorhombic and monoclinic crystals: C.H. Wei, G.R. Wilkes, P.M. Treichel and L.F. Dahl, Inorg. Chem., 5 (1966) 901; R.A. Schunn, C.J. Fritchie and C.T. Prewitt, ibid., 5 (1966) 892. Also, $\left(\mathrm{C}_{5} \mathrm{H}_{5}\right)_{2} \mathrm{TiS}_{5}$ was found to be monoclinic by E.F. Epstein, I. Bernal and H. Kopf, J. Organomet. Chem., 26 (1971) 229 and orthorhombic by E.J. Muller, J.L. Pettersen and L.F. Dahl, ibid., 111 (1976) 91.

4 G.M. Reisner, I. Bernal and G.R. Dobson, J. Organomet. Chem., 157 (1978) 23.

5 R.B. Roof, Jr., A Theoretical Extension of the Reduced Cell Concept in Crystallography, Report LA-4038, Los Alamos Scientific Laboratory, 1969.

6 Program BMFIT by L.-K. Liu, University of Texas, Austin, 1977; based on a suggestion by S.C. Nyburg, Acta Crystallogr. B, 30 (1974) 251. This program was modified at the University of Houston by S.F. Watkins, J.D. Korp and M.W. Creswick. 